\title{
PENINGKATAN MOTIVASI DAN HASIL BELAJAR IPA FISIKA MELALUI PENERAPAN METODEEKSPOSITORI DAN TEKNIK DRILL KELAS XI-TBSM SMK NEGERI 1 NARMADA KABUPATEN LOMBOK BARAT TAHUN PELAJARAN 2018-2019
}

\author{
H. M. Yusuf AS ${ }^{1)}$, Munawir'1), Lalu Syaifulbakhry1) \\ 1)SMKN 1 Narmada, Kabupaten Lombok Barat, NTB, Indonesia \\ Corresponding author: H. M. Yusuf AS \\ E-mail : hajiyusuf64@gmail.com
}

Diterima 04 Oktober 2021, Direvisi 20 Oktober 2021, Disetujui 20 Oktober 2021

\begin{abstract}
ABSTRAK
Faktor-faktor yang mempengaruhi belajar dapat memberikan dukungan yang positif dalam belajar, namun dapat juga menghambat proses belajar. Hambatan-hambatan yang terjadi berakibat pada hasil belajar individu yang mengalami proses belajar tidak sesuai dengan yang diinginkannya. Keadaankeadaan tersebut berdampak pada timbulnya masalah pada proses belajar selanjutnya. Motivasi belajar siswa yang rendah akan menjadi hambatan yang sangat berarti pada proses pembelajaran, karena dapat mengakibatkan prestasi belajar siswa rendah. Oleh karena itu guru diharapkan dapat meningkatkan motivasi belajar siswa untuk meningkatkan prestasi belajar siswa. Rendahnya motivasi dan hasil belajar siswa disebabkan siswa kurang diberikan kesempatan untuk bertanya dan menyampaikan pendapat. Metode pembelajaran ekspositori dan teknik drill dipercaya dapat menigkatkan motivasi belajarsehingga diharapkan dapat meningkatkan kegiatan belajar IPA Fisika untuk memperbaiki hasil belajar selanjutnya. Karena metode ekspositori dan teknik drill memberikan kesempatan peserta didik untuk lebih aktif. Oleh karena itu penulis perlu melakukan penelitian Tindakan dengan judul Peningkatan Motivasi dan Hasil Belajar IPA Fisika Melalui Penerapan MetodeEkspositori dan Teknik Drill Kelas XI-TBSM SMK Negeri 1 Narmada Kab. Lombok Barat Tahun pelajaran 20182019.
\end{abstract}

Kata Kunci: ekspositori; drill; motivasibelajar; hasil belajar.

\begin{abstract}
Factors that influence learning can provide positive support in learning, but can also hinder the learning process. The obstacles that occur result in the learning outcomes of individuals who experience the learning process not in accordance with what they want. These circumstances have an impact on the emergence of problems in the subsequent learning process. Low student motivation will be a very significant obstacle in the learning process, because it can result in low student achievement. Therefore, teachers are expected to increase students' learning motivation to improve student achievement. The low motivation and student learning outcomes are caused by the lack of opportunities for students to ask questions and express opinions. Expository learning methods and drill techniques are believed to increase learning motivation so that it is expected to increase Physics Science learning activities to improve subsequent learning outcomes. Because the expository method and drill technique provide opportunities for students to be more active. Therefore, the authors need to conduct action research with the title Improving Motivation and Learning Outcomes of Physics Sciences Through the Application of Expository Methods and Drill Techniques for Class XI-TBSM SMK Negeri 1 Narmada2018-2019 Academic year.
\end{abstract}

Keywords: expository; drill; learning motivation; learning outcomes.

\section{PENDAHULUAN}

Faktor-faktor yang mempengaruhi belajar dapat memberikan dukungan yang positif dalam belajar, namun dapat juga menghambat proses belajar. Hambatan-hambatan yang terjadi berakibat pada hasil belajar individu yang mengalami proses belajar tidak sesuai dengan yang diinginkannya. Keadaan-keadaan tersebut berdampak pada timbulnya masalah pada proses belajar selanjutnya. Motivasi belajar siswa yang rendah akan menjadi hambatan yang sangat berarti pada proses pembelajaran, karena dapat mengakibatkan prestasi belajar siswa rendah. Oleh karena itu guru diharapkan dapat meningkatkan motivasi 
belajar siswa untuk meningkatkan prestasi belajar siswa.

Permasalahan belajar seperti yang diungkapkan tersebut terjadi pada siswa kelasXI-TBSM di SMK Negeri 1 Narmada. Hal ini ditunjukkan dengan pencapaian nilai IPA Fisika yang rendah. Banyak siswa yang memperoleh nilai IPA Fisika di bawah 60, tidak sesuai dengan yang KKM yang telahditetapkan. Anggapan tentang sulitnya belajar IPA Fisika sering mendominasi pemikiran siswa sehingga banyak di antara mereka kurang berminat untuk mempelajari IPA Fisika, sehingga siswa kurang termotivasi dalam belajar. Selain itu, pembelajaran juga masih terpusat pada guru. Guru banyak menjelaskan dan siswa kurang diberi kesempatan untuk berdiskusi dengan temannya.

Berdasarkan observasi peneliti di sekolah yang dilakukan pada bulan Agustus tahun 2018 dan wawancara dengan teman guru IPA Fisika, 18 dari 30 siswanya kurang memahami pelajaran IPA Fisika hal ini dilihat dari nilai tes IPA Fisika yang kurang dari 60. Berdasarkan hasil pengamatan, bahwa motivasi dan hasilbelajar IPA Fisika siswa rendah. Rendahnya motivasi dan hasil belajar siswa dapat dilihat pada saat siswa menerima materi pelajaran. Hal ini ditunjukkan dengan sikap siswa yang cenderung ramai sendiri, mengobrol dengan teman, ada beberapa siswa yang mengerjakan PR pelajaran lain dan kurang memperhatikan pembelajaran yang sedang berlangsung. Bila siswa diberi latihan soal yang agak sulit, siswa tidak mengerjakan soal tersebut dan tidak termotivasi untuk mencari penyelesaian dari soal tersebut. Siswa lebih senang menunggu guru menyelesaikan soal tersebut. Hal ini disebabkan siswa kurang diberikan kesempatan untuk bertanya dan menyampaikan pendapat.Penggunaan gabunganmetode pembelajaran ekspositori dan teknik drill dapat menigkatkan motivasi belajar IPA Fisika, sehingga diharapkan dapat meningkatkan kegiatan belajar IPA Fisikauntukmemperbaiki hasil belajar selanjutnya. Dengan menerapkan metode ini, pembelajaran tidak hanya terpusat pada guru tetapi siswa bisa lebih aktif dalam pembelajaran.

Berdasarkan pada permasalahan tersebut perlu dilaksanakan penelitian tindakan pelajaran IPA Fisika menggunakan metode ekspositori dan teknik drill untuk memotivasi belajar IPA Fisika siswa. Melaluipenerapan metode ekspositori dan teknik drillini diharapkan dapat menjadi salah satu solusi dalam mengatasi rendahnya motivasi dan hasilbelajar yang dialami oleh siswa.

\section{METODE PENELITIAN Subjek Penelitian}

Penelitian ini merupakan penelitian tindakan kelas, yang dilakukan secara bertahap-tahap sampai mendapatkan hasil yang diinginkan. Jumlah siswa kelas XI-TBSM secara keseluruhan yaitu 33 orang.

\section{Setting Penelitian}

1. PTK dilakukan diSMK Negeri 1 Narmada Tahun Pelajaran 2018-2019

2. Kelas XI di SMK Negeri 1 Narmada terdiridari 6kelas dan jumlah siswa tiap kelas relatif cukup besar dibandingkan dengan sekolah lainnya di wilayah kabupaten Lombok Barat.

3. PTK dilakukan pada siswa kelas XI-TBSM dengan jumlah 33 orang $(P=17$ orang dan $\mathrm{L}=16$ orang ).

\section{Rancangan Penelitian}

1. Tindakan dilaksanakan dalam 3 siklus

2. Kegiatan dilaksanakan dalam semester ganjil tahun pelajaran 2018-2019

3. Lama penelitian 6 pekan efektif dilaksanakan mulai tanggal 08 September 2018 sampai dengan 14 Oktober 2018 .

\section{Variabel Penelitian}

Dalam penelitian tindakan kelasini Variabel yang diteliti adalah peningkatan motivasi dan hasilbelajarIPA Fisika melalui penerapanmetode ekspositori dan teknik drill kelas XI-TBSM SMK Negeri 1 Narmada Kabupaten Lombok Barat.

Variabel tersebut dapat dituliskan kembali sebagai berikut :

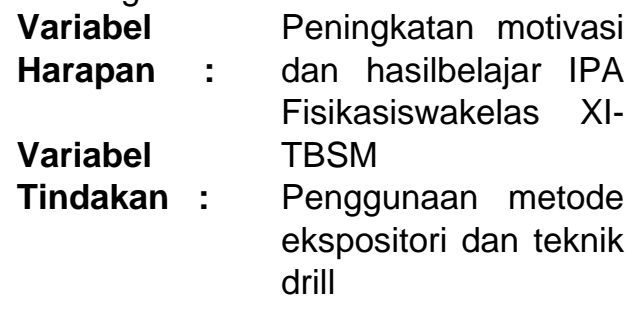

Adapun indikator yang diteliti dalam

Variabel harapan terdiri dari:

1. Kemampuan meningkatkan motivasi dan hasilbelajar IPA Fisika siswa

2. Kemampuan siswa dalam proses pembelajaran IPA Fisikamelaluipenerapanmetode ekspositori dan teknik drill

3. Keefektifan pembelajaran IPA Fisika melalui penerapanmetode ekspositori dan teknik drill.

Sedangkan Variabel tindakan memiliki indikator sebagai berikut :

1. Tingkat kualitas perencanaan

2. Kualitas perangkat observasi

3. Kualitas operasional tindakan 
4. Kesesuaian perencanaan dengan tindakan kelas

5. Kesesuaian teknik yang digunakan meningkatkan motivasi dan hasilbelajar siswa pelajaran IPA Fisika.

6. Tingkat efektifitas pelaksanaan pembelajaran dengan penggunaan metode ekspositori dan teknik drill.

7. Kemampuan siswa dan gurudalam menerapkan metode ekspositori dan teknik drill.

\section{Teknik Analisis Data}

Dalam analisis data teknik yang digunakan adalah ;

\section{Kuantitatif}

Analisis ini digunakan untuk menghitung besarnya peningkatan hasil belajar siswa pelajaran IPA Fisikadengan menerapkan metode ekspositori dan teknik drill dengan menggunakan prosentase ( \% ).

\section{Kualitatif}

Teknik analisis ini digunakan untuk memberikan gambaran hasil penelitian secara ; reduksi data, sajian deskriptif, dan penarikan simpulan.

\section{HASIL DAN PEMBAHASAN}

\section{Pelaksanaan Tindakan dan Pengamatan}

Setelah dilakukan tindakan pada siklus

1 , siklus 2 dan siklus 3 menunjukkan hasil sebagai berikut.

Tabel 1. Analisis Hasil Tes Pelajaran IPA Fisika dalam Meningkatkan Prestasi belajar siswa dengan menerapkan Metode ekspositori dan teknik drill.

\begin{tabular}{lccc}
\cline { 2 - 4 } & $\begin{array}{c}\text { Skor } \\
\text { sebelum }\end{array}$ & $\begin{array}{c}\text { Skor } \\
\text { setelah }\end{array}$ & Skor setelah \\
\cline { 2 - 4 } & Tindakan & $\begin{array}{c}\text { Tindakan } \\
1\end{array}$ & Tindakan 2 \\
\cline { 2 - 4 } & Siklus 1 & Siklus 2 & Siklus 3 \\
\hline $\begin{array}{l}\text { Jumlah } \\
\text { Skor Maksimum }\end{array}$ & 1305 & 2176 & 2509 \\
$\begin{array}{l}\text { Individu } \\
\text { Skor Maksimum }\end{array}$ & 100 & 100 & 100 \\
$\begin{array}{l}\text { Kelas } \\
\text { Jumlah siswa }\end{array}$ & 3300 & 3300 & 3300 \\
$\begin{array}{l}\text { yang tuntas } \\
\text { Jumlah siswa yg } \\
\text { belum tuntas }\end{array}$ & 11 & 23 & 32 \\
$\begin{array}{l}\text { Nilai rata-rata } \\
\text { Ketuntasanklasikal }\end{array}$ & 39,55 & 65,94 & 76,03 \\
\hline
\end{tabular}

\section{Analisis Data Deskriptif Kuantitatif}

1. Pencapaian hasil belajar siswa kelas $\mathrm{XI}$ TBSM sebelum diberi tindakan

$$
=\underline{1305} \times 100=39,55
$$

2. Pencapaian hasil belajar siswa kelas $\mathrm{XI}$ TBSM setelah diberi tindakan pengelompokan siswa berdasarkan nomor panggilan (acak berdasarkan tempat duduk)

$$
=\frac{2176}{3300} \times 100=65,94
$$

3. Pencapaian hasilbelajar siswa kelas XITBSM setelah diberi tindakan pengelompokan siswa berdasarkan kemampuan akademik

$$
\begin{aligned}
& =\frac{2509}{3300} \times 100=76,03 \\
& \text { Dari hasil analisis tersebut dapat }
\end{aligned}
$$

disimpulkan bahwa

1. Terjadi peningkatan prestasi setelah diberi tindakan yaitu 39,55 menjadi 65,94 ada kenaikan sebesar $=30,39$

2. Dari sebelum tindakan (siklus 1 ) dan setelah tindakan sampai dengan (siklus 3) 39,55 menjadi 65,94, dan dari (siklus 2) ke (siklus 3) juga ada peningkatan sebanyak $76,03-65,94=10,09$.

3. Rata - rata siswa sebelum diberi tindakan dari $33,33 \%$ menjadi $96,97 \%$.

4. Dari tindakan siklus 2 dan setelah tindakan (siklus 3) 65,94 menjadi 75,03 berarti ada peningkatan prestasi sebanyak 76,03 $65,94=10,09$.

Berdasarkan hasil penelitian di atas, maka hasil belajar siswa dengan menerapkan metodeekspositori dan teknik drill hasilnya sangat baik. Hal itu tampak pada pertemuan dari 33 orang siswa yang hadir pada saat penelitian ini dilakukan nilai rata rata mencapai 39,55 meningkat menjadi 65,94 dan pada siklus 3 meningkat menjadi 76,03 .

Dari analisis data di atas bahwa penerapanmetode ekspositori dan teknik drilldalamkegiatan belajar mengajar lebih berhasil dan dapat meningkatkan aktivitas belajar IPA Fisika siswa khususnya pada siswa kelas XI-TBSM di SMK Negeri 1 Narmada. Dengan demikian maka hipotesis yang diajukan dapat diterima.

\section{SIMPULAN DAN SARAN}

Dari hasil kegiatan pembelajaran yang telah dilakukan selama tiga siklus, dan berdasarkan seluruh pembahasan serta analisis yang telah dilakukan dapat disimpulkan sebagai berikut 1) Pembelajaran dengan menerapkan metode ekspositori dan teknik drill dalam meningkatkan motivasi dan hasilbelajar IPA Fisikasiswa kelas XI-TBSM di SMK Negeri 1 Narmada yang ditandai dengan peningkatan hasil belajar siswa dalam setiap siklus, yaitu; 39,55 ; 65,94 ; 76,03; 2) Penerapan metode ekspositori dan teknik drill pada pelajaran IPA Fisika mempunyai pengaruh positif, yaitu dapat meningkatkan aktivitas belajar siswa; dan 3) 
Penerapan metode ekspositori dan teknik drillefektifuntuk meningkatkan kembali materi ajar yang telah diterima siswa selama ini, sehingga mereka merasa siap untuk menghadapi pelajaran berikutnya.

Dari hasil penelitian yang diperoleh dari uraian sebelumnya agar proses belajar mengajar di SMK lebih efektif dan lebih memberikan hasil yang optimal bagi siswa, maka disampaikan saran sebagai berikut 1) Untuk melaksanakan pembelajaran memerlukan persiapan yang cukup matang, sehingga guru harus mampu menentukan atau memilih topik yang benar-benar bisa diterapkan dengan pemberian metode ekspositori dan teknik drillagar diperoleh hasil yang optimal; 2) Dalam rangka meningkatkan motivasi dan hasilbelajar siswa, guru hendaknya lebih sering melatih siswa dengan kegiatan penemuan, walau dalam taraf yang sederhana, di mana siswa nantinya dapat menemukan pengetahuan baru, memperoleh konsep dan keterampilan, sehingga siswa berhasil atau mampu memecahkan masalah-masalah yang dihadapinya; dan 3) Perlu adanya penelitian yang lebih lanjut, karena hasil penelitian ini hanya dilakukan di SMK Negeri 1 Narmada Tahun Pelajaran 2018-2019

\section{UCAPAN TERIMAKASIH}

Terima kasih penulis sampaikan kepada Kepala Sekolah SMKN 1 Narmada yang telah mendukung kegiatan penelitian ini sehingga bisa selesai tepat pada waktunya.

\section{DAFTAR RUJUKAN}

Anonim. (2004). Model IPA Fisika SMK . http://www.google.co.id/search?hl=en $\& \mathrm{cr}=$ country|D\&q=modelmodel+pembelajaran \&start $=10 \& s a=\mathrm{N}$. Diakses 2 April 2008

Anonim. (2005). Membangkitkan Motivasi Belajar Siswa. http://www.bruderfic.or.id/h-129/peranguru-dalam-membangkitkan-motiVasibelajar-siswa.html. Diakses 28 Juni 2008

Elida Prayitno. (1989). Motivasi dalam Belajar. Jakarta: Depdikbud.

Endang Supartini. (2001). Diagnosis Kesulitan Belajar dan Pengajaran Remedial. Yogyakarta: FIP-UNY.

Erman Suherman, Turmudi, Didi Suryadi, Tatang Herman, Suhendra, Sufyani Prabawanto, Nurjanah, Ade Rohayat. (2003). Strategi Pembelajaran IPA Fisika Kontemporer. Bandung: Jurusan Pendidikan IPA Fisika FMIPA FISIKA UPI.
Frith, Constance. MotiVation to Learn. http://www.usask.ca/education/ coursework/802papers/

Frith/MotiVation.HTM. Diakses 1 September 2008

Herman Hudojo. (1988). Megajar Belajar IPA Fisika. Jakarta: Depdikbud.

(2001). Pengembangan Kurikulum dan Pembelajaran IPA Fisika. Jurusan Pendidikan IPA Fisika FMIPA FISIKA UniVersitas Negeri Malang.

Moh. Uzer USMKN. (1993). Upaya Optimalisasi Kegiatan Belajar Mengajar. Bandung: Rosdakarya.

Muhibbin Syah, M.Ed. (2002). Psikologi Belajar. Jakarta: Rajawali Pers.

Nana Sudjana dan Ibrahim. (2001). Penelitian dan Penilaian Pendidikan. Bandung: Sinar Baru Bandung.

Ratna Willis Dahar. (1996). Teori-teori Belajar. Jakarta: Erlangga.

Rochiati Wiriatmadja. (2006). Metode Penelitian Tindakan Kelas. Bandung: Remaja Rosdakarya.

Saifuddin Azwar. (1996). Tes Prestasi Fungsi dan Pengembangan Pengukuran Prestasi Belajar. Yogyakarta: Pustaka Belajar.

Sardiman A. M. (1996). Interaksi dan Motivasi Belajar Mengajar. Jakarta: Raja Grafindo Persada.

Sartono Wirodikromo. (2004). IPA Fisika untuk SMK Kelas XI IPA. Jakarta: Erlangga.

Slameto. (1991). EValuasi Pendidikan. FKIP UKSW Salatiga: Bumi Aksara.

Sri Rumini. (2003). Diagnosis Kesulitan Belajar. Yogyakarta: FIP-UNY

Suharsimi Arikunto. (2003). Dasar-dasar Evaluasi Pendidikan. Jakarta: Rineka Cipta

Suryawahyuni Latief. (2008). Meningkatkan MotiVasi Belajar. http://202.152.33.84/index.php?option =com_content\&task=View\&id $=13377 \&$ Itemid $=46$. Diakses 26 Mei 2008

Susiyana. (2006). Upaya Meningkatkan MotiVasi Belajar IPA Fisika Siswa melalui Model Pembelajaran Metode Ekspositori di SMK Muhammadiyah 4 Yogyakarta Kelas X. Skripsi. Yogyakarta: Jurdik IPA Fisika FMIPA FISIKA UNY.

Utami Munandar. (1992). Mengembangkan Bakat dan Kreatifitas Anak sekolah. Jakarta: Gramedia.

Winkel. (1991). Psikologi Pembelajaran. Jakarta: Grasindo. 